\title{
Palaeomagnetism of pseudotachylites from the Ikertôq shear belt, and their relationship to the kimberlite-lamprophyre province, central-west Greenland
}

\author{
J. D. A. PIPER
}

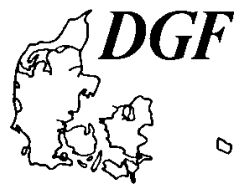

Piper, J. D. A.: Palaeomagnetism of pseudotachylites from the Ikertôq shear belt, and their relationship to the kimberlite-lamprophyre province, central-west Greenland. Bull. geol. Soc. Denmark, vol. 30, pp. 57-67. Copenhagen, November 12th, 1981. https://doi.org/10.37570/bgsd-1981-30-05

\begin{abstract}
Pseudotachylite veins from the northern margin of the Ikertôq shear belt possess a highly-stable remanence residing in magnetite. Sites in seven veins define a mean axis of magnetisation $D=269^{\circ}, I=22^{\circ}$ $(\mathrm{k}=23)$ with one vein possessing opposite polarity to the remainder. The palaeomagnetic results show that brittle fracture events represented by the pseudotachylites occurred during a single episode. Similar directions of magnetisation in some of the kimberlite-lamprophyre dykes intruding the Ikertôq belt demonstrate a close temporal relationship between the pseudotachylites and the earlier part of the (c. $580 \mathrm{Ma}$ ) kimberlite/lamprophyre magmatism. The pseudotachylites include the oldest glass identified to date. The kimberlites and lamprophyres have a non-Fisherian distribution of magnetic remanence directions indicating intrusion during an interval of rapid and appreciable apparent polar wander (a.p.w.) movement in latest Precambrian times. Intersecting relationships define this motion as from shallow to steep palaeolatitudes. In general, emplacement of the kimberlites and lamprophyres took place earliest near the axis of the Ikertôq belt (probably just prior to the pseudotachylite formation) and latest near the margins of the belt where it appears to have continued into Palaeozoic times. The collective palaeomagnetic data show that Greenland moved rapidly across the south pole in latest Precambrian earliest Cambrian times, and accord with the stratigraphic position of the southern Peary Land tillite.
\end{abstract}

J. D. A. Piper, Sub-Department of Geophysics, University of Liverpool, P. O. Box 147, Liverpool L69 3BX, England, May 6th 1981.

Two major phases of ductile deformation are recognised in the Nagssugtoqidian mobile belt of West Greenland (Bridgwater et al. 1973). The first (Nag 1) produced major shear belts and was followed by the emplacement of the Kangamiut dykes. A later (Nag 2) phase locally deformed and metamporphosed these dykes into strongly sheared amphibolites; it profoundly affected the Sarfanguaqland area which is the location of the present study. Later brittle fracture movements are represented by thin pseudotachylite veins and breccias. These have strike directions close to the gneiss fabrics (Bak et al. 1975) and occur throughout the Ikertôq shear belt although they are most common within $5 \mathrm{~km}$ of the northern and southern boundaries. This study is concerned with the pseudotachylites concentrated near the northern margin of the belt (Fig. 1) where the sampling sites are distributed across a width of $5 \mathrm{~km}$; the entire Ikertôq shear belt has a width of approximately $40 \mathrm{~km}$ (see inset, Fig. 4).
The ages of the brittle fracture events represented by these pseudotachylites have not hitherto been clear: at site 2 (Fig. 1) unaltered glass is present (J. Grocott, pers. communication) and only rarely has glass older than midTertiary survived (Marshall 1961). However, near site 5 pseudotachylite postdates a member of the kimberlite-lamprophyre dyke suite intruded in the Ikertôq shear belt and its margins (Escher and Watterson 1973). Phlogopite K-Ar and $\mathrm{Rb}-\mathrm{Sr}$ whole-rock determinations on members of this suite yield ages of 590-570 Ma (Bridgwater 1971, Scott 1981, MacIntyre et al. 1979). Where intersecting relationships are observed the bulk of the pseudotachylites are seen to predate the kimberlites (J. Watterson, pers. communication).

The palaeomagnetic study of the pseudotachylites has been undertaken i) to determine whether or not the brittle fracture events represent a single coherent episode, and ii) to esti- 


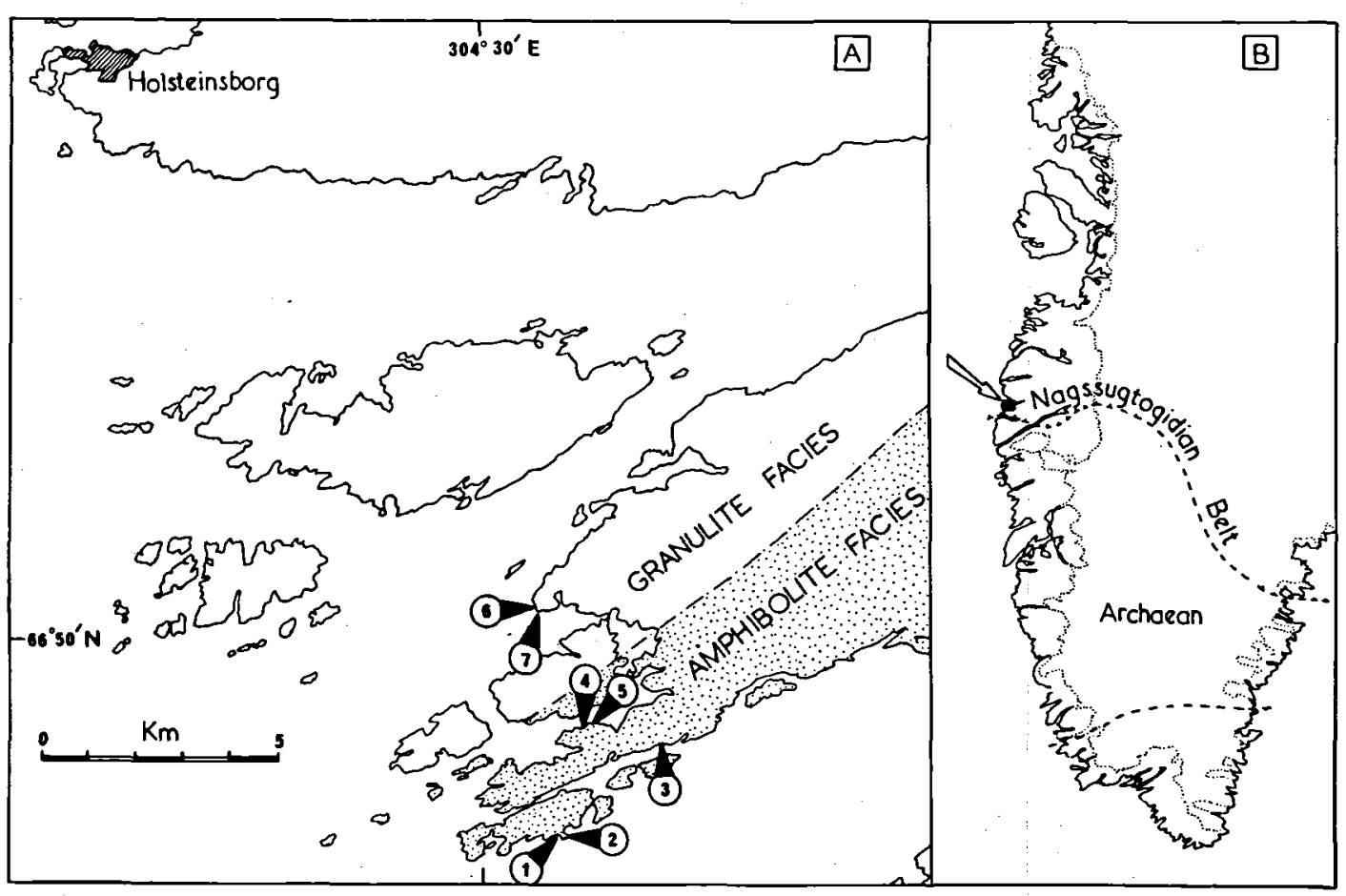

Fig. 1. A. Location of the palaeomagnetic sampling sites in pseudotachylites at the northern margin of the Ikertôq Shear Belt, West Greenland; stippled areas are amphibolite facies terrain and blank areas are granulite facies terrain. B. Regional situation of the area of study within the Nagssugtoqidian mobile belt.

mate the age or ages of the events from the palaeomagnetic poles and establish their relationship to the kimberlite-lamprophyre suite.

\section{Palaeomagnetic results}

Palaeomagnetic cores were drilled from the pseudotachylite veins with a portable diamond drill (Doell \& Cox 1967) and oriented by solar compass. All cores were progressively demagnetised in the laboratory in increasing alternating fields (a.f.) in steps of 5 milliTesla (mT) to peak fields of up to $160 \mathrm{mT}$; measurements were made with an automated parastatic magnetometer system. All samples possess strong (233-0.5 A. $\mathrm{m}^{2} / \mathrm{kg}$ ) and coherent total NRM's unrelated to the present field and falling exponentially with progressive a.f. treatment (Fig. 2). This behaviour is characteristic of titanomagnetite

Table 1

Palacomagnetic results for pseudotachylites from the Nagssugtotidian mobile belt, central West Greenland.

\begin{tabular}{lrrrrrrrr}
\hline $\begin{array}{l}\text { Site } \\
\text { No. }\end{array}$ & $\mathrm{N}$ & $\mathrm{D}$ & $\mathrm{I}$ & $\mathrm{R}$ & $\mathrm{k}$ & \multicolumn{1}{c}{$\alpha_{95}$} & $\begin{array}{c}\text { Curie Point } \\
\left( \pm 10^{\circ} \mathrm{C}\right)\end{array}$ & $\begin{array}{c}\mathbf{J}_{\mathrm{o}} \\
\left(\mathrm{A} \cdot \mathrm{m}^{2} / \mathrm{kg}\right)\end{array}$ \\
\hline 1 & 6 & 280.5 & 31.4 & 5.82 & 27 & 13.0 & 575 & $2.11-0.88$ \\
2 & 7 & 271.4 & 9.2 & 6.76 & 25 & 12.4 & 580 & $15.21-9.16$ \\
3 & 18 & 95.8 & -37.2 & 17.55 & 37 & 5.7 & 565 & $233.66-9.36$ \\
4 & 7 & 255.6 & 27.7 & 6.83 & 36 & 10.3 & 565 & $42.19-0.49$ \\
5 & 3 & 256.5 & 32.2 & 2.77 & 9 & 45.0 & 560 & $15.94-2.51$ \\
6 & 8 & 282.2 & 13.3 & 7.97 & 212 & 3.8 & 555 & $4.11-0.91$ \\
7 & 7 & 260.3 & 3.3 & 6.99 & 704 & 2.3 & 560 & $17.64-4.40$ \\
\end{tabular}

$D$ is the mean declination in ${ }^{\circ} \mathrm{E}$ and $\mathrm{I}$ the inclination of the remanence from $\mathrm{N}$ samples with resultant vector $\mathrm{R}$, and precision parameter $k(=(\mathrm{N}-1) /(\mathrm{N}-\mathrm{R})) ; \alpha_{95}$ is the radius of the 95 percent confidence oval about the mean direction. 


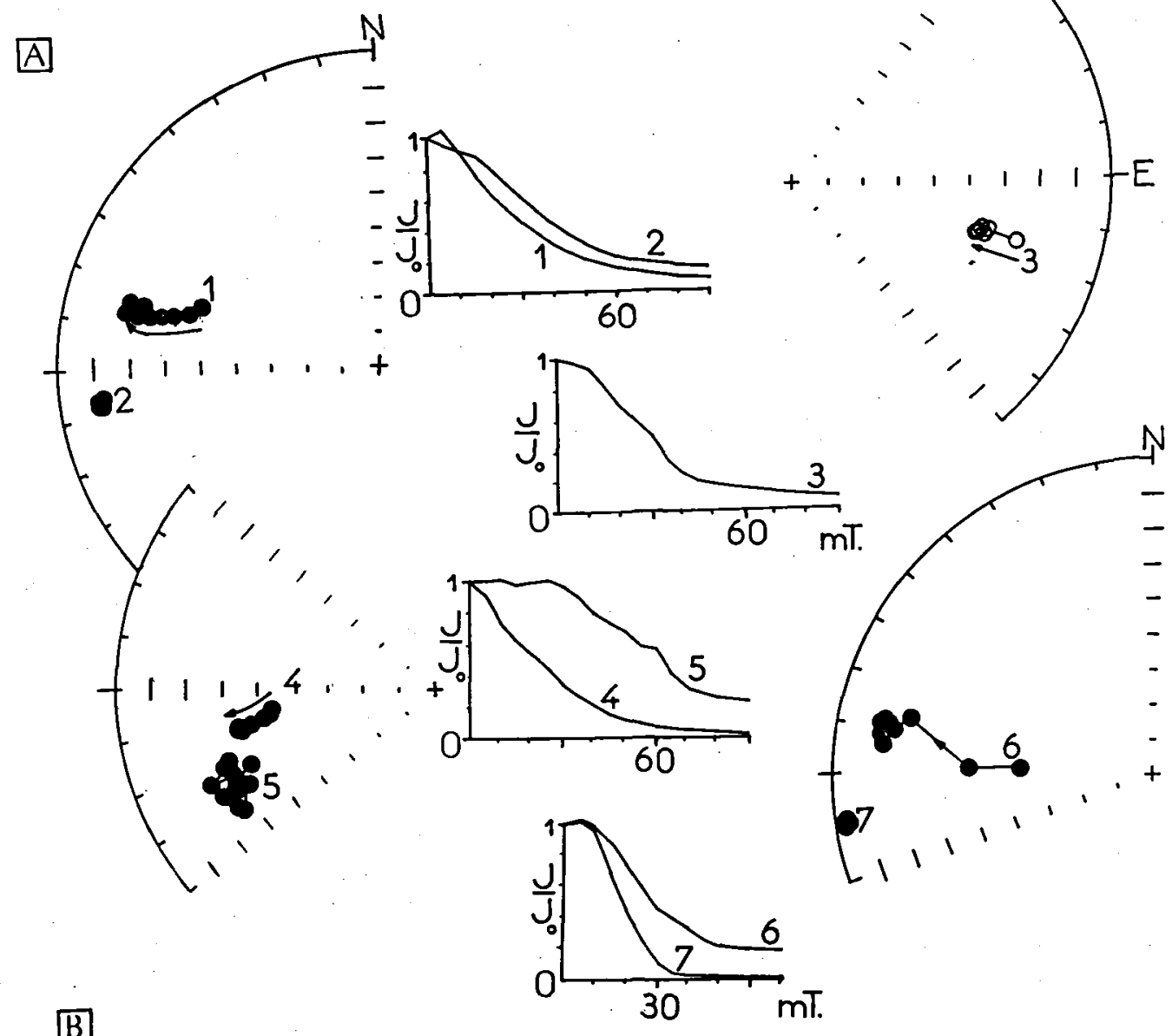

B]
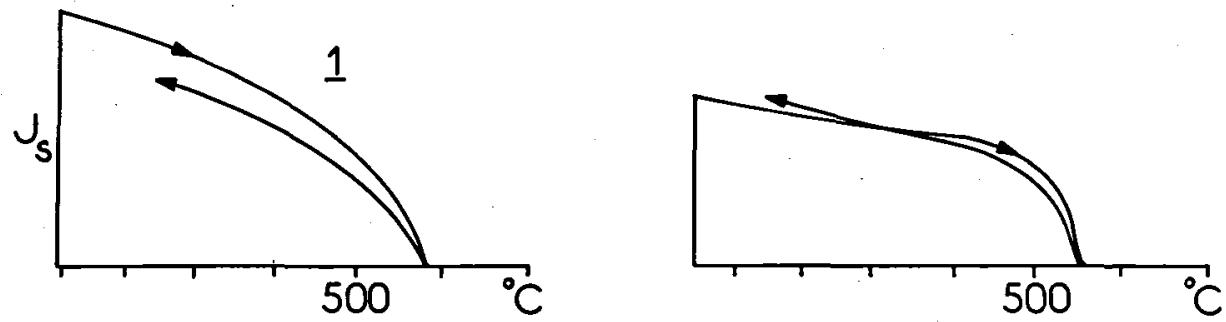

Fig. 2. Behaviour of directions and magnetic moments (expressed as a fraction of the initial moment, $J_{0}$ ) of some pseudotachylite samples with progressive a.f. cleaning. Numbers are site numbers, closed symbols are lower hemisphere plots and open symbols are upper hemisphere plots. Also illustrated are representative thermomagnetic determinations of saturation magnetisation, $J_{s}$, as a function of temperature.

(Nagata 1967) and thermomagnetic determinations all yield single Curie points (Fig. 2 and Table 1) between 555 and $580^{\circ} \mathrm{C}$ close to pure magnetite $\left(\mathrm{T}_{\mathrm{c}} \sim 575^{\circ} \mathrm{C}\right)$.

With cleaning treatment samples exhibit either no change in direction or move to slightly more negative inclinations implying removal of a small steeper positive, possibly a present field, component. Stable end points are rapidly achieved by median destructive fields in excess of $20 \mathrm{mT}$ (Fig. 2) with intermediate to shallow westerly or easterly directions and retained to the highest available fields $(\sim 160 \mathrm{mT})$. Site 3 is reversed with respect to the remaining sites and 


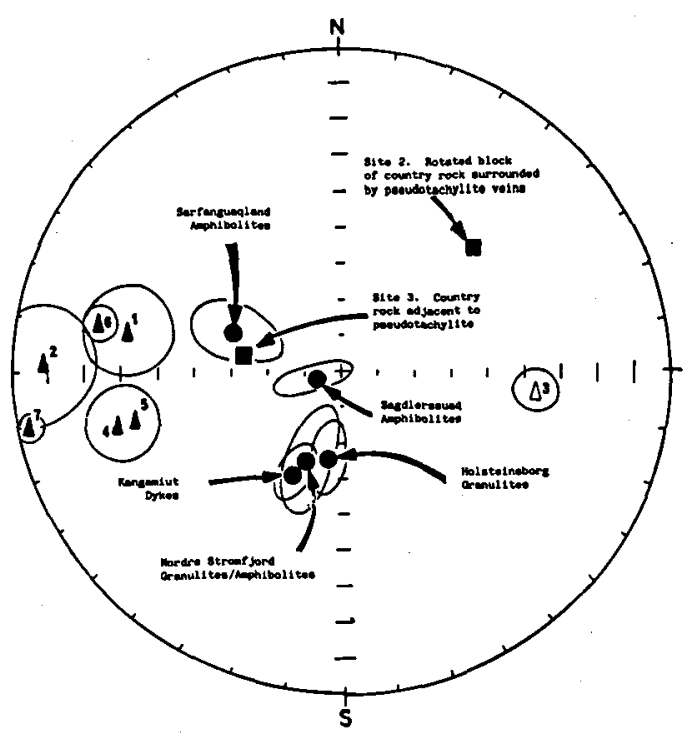

Fig. 3. Directions of magnetisation and 95 percent confidence circles for the pseudotachylite veins of this study and basement rocks of the Nagssugtogidian belt in this area.

shows that formation of the pseudotachylites spanned at least one polarity interval. Site mean directions and statistics are listed in Table 1; the group mean is calculated by reversing site 3 and assuming that all the pseudotachylites represent an event spanning a discrete time interval $\left(\sim 10^{6}-\right.$ $10^{7}$ years). Site dispersion (k) here is, in part, a function of the difficulty of orienting very short cores from this exceptionally hard material in thin veins, and does not adequately reflect the high magnetic stability of the material; in a few cases orientation measurements are estimated to be accurate to only $\pm 5^{\circ}$ compared with $\pm 1^{\circ}$ normally achieved for long cores.

It seems likely that remagnetisation effects of the events forming the pseudotachylites are very local: cores including segments of both vein and country rock have a magnetisation dominated by the pseudotachylite but gneiss samples at site 3 removed more than $1 / 2$ metre from any visible pseudotachylite have a magnetisation ( 3 in Fig. 3) identical to the basement amphibolites. Three samples from a single block of country rock surrounded by pseudotachylites ( 2 in Fig. 3 ) have a rotated remanence vector; disturbance of the mineral foliation here shows that this block has been rotated during formation of the veins.

\section{Interpretation}

(i) The pseudotachylite episode

The palaeomagnetic directions form essentially a single group although the magnetic declination ranges from 3 to $37^{\circ}$ which is slightly greater than would be expected from secular variation alone at this palaeolatitude (Irving 1964, p. 70). This demonstrates that the brittle fracture events represented by the pseudotachylites were confined to a short episode which did not involve appreciable apparent polar wander (a.p.w.) motion although it was long enough to incorporate at least one polarity reversal; (Phanerozoic field reversals are believed to have been accomplished during periods of the order of $5 \times 10^{3}$ years).

(ii) Maximum and Minimum ages estimates

The magnetisation of the basement amphibolites and granulites within the Nagssugtoqidian terrain of West Greenland is now fairly well understood from the work of Fahrig \& Bridgwater (1976), Morgan (1976) and Beckman \& Mitchell (1976). It is believed to have been acquired during the slow uplift and cooling of this plutonic terrain at times approximately defined by $\mathrm{K}$-Ar mineral whole rock and isochron ages in the range 1790-1620 Ma (Morgan 1976, Beckmann \& Mitchell 1976); considerable doubt however surrounds the age of the metamorphic magnetisations south of Itivdleq fjord (cf. Fahrig \& Bridgwater 1976 and Beckmann 1979). The directions of magnetisation from these studies have only one polarity and steep to intermediate inclination (Fig. 3). In addition, amphibolites from six localities on Sarfanguaqland yield a coherent magnetite-held remanence with a mean after cleaning of $\mathrm{D}=291^{\circ}, \mathrm{I}=59^{\circ}$ $(\mathrm{R}=5.8, \mathrm{k}=23)$. This is closer to the mean direction from the Sagdlerssauq amphibolites (Beckmann \& Mitchell 1976) than the mean from the granulite facies, and tentatively suggests that the magnetic record in amphibolite facies terrains of the Nagssugtoqidian Belt is appreciably different from the granulite facies terrains in the Itivdleq fjord and Holsteinsborg areas. Under conditions of protracted cooling magnetic blocking temperature ranges are lowered and broadened (Pullaiah et al. 1975) to an extent which will depend both on the rate of uplift and magnetic mineralogy. In the case of 
the Nagssugtoqidian terrain, magnetisation temperatures may have been as low as 350$250^{\circ} \mathrm{C}$ (Morgan 1976). Thus the wide difference between the pseudotachylite and amphibolite/ granulite remanence directions (Fig. 3) shows firstly that the area has not been subjected to a widespread blanket remagnetisation in later times, and secondly that the pseudotachylites were formed after the basement rocks had cooled to low temperatures.

To obtain an estimate of the age of the pseudotachylite palaeomagnetic pole by comparison with the North American a.p.w. path the site and mean poles are rotated in Table 2 to close the Davis Strait according to to the conventional reconstruction of Bullard et al. (1965). The palaeopoles are then identical to $c a .1300$ m.y. poles from North America and the earliest phases of the Gardar igneous activity in South Greenland (Irving \& McGlynn 1976, Piper 1977). However, it is not considered that this is a realistic possibility for the age of pseudotachylite formation because (i) it is very unlikely that glass could survive for $1300 \mathrm{Ma}$; (ii) at least one of the pseudotachylite veins cuts a kimberlite dyke and radiometric studies show that the kimberlite magmatism is latest Precambrian - early Cambrian in age. The possibility of a post-Middle Ordovician age is however also excluded because this pole is remote from poles of Ordovician and younger age from North

Table 2

Virtual geomagnetic pole positions from West Greenland pseudotachylites and pole positions with respect to North America after correction for Phanerozoic plate motions*

\begin{tabular}{|c|c|c|c|c|c|}
\hline \multirow[t]{2}{*}{ Site No. } & \multicolumn{2}{|c|}{ Pole Positions } & \multirow[t]{2}{*}{$\mathrm{dp} / \mathrm{dm}$} & \multicolumn{2}{|c|}{$\begin{array}{l}\text { Corrected } \\
\text { Pole Position }\end{array}$} \\
\hline & ${ }^{\circ} \mathrm{E}$ & ${ }^{\circ} \mathrm{N}$ & & ${ }^{\circ} \mathrm{E}$ & ${ }^{\circ} \mathrm{N}$ \\
\hline 1 & 214 & 20 & $8 / 15$ & 198 & 25 \\
\hline 2 & 217 & 5 & $6 / 13$ & 201 & 10 \\
\hline 3 & 39 & -21 & $4 / 7$ & 24 & -26 \\
\hline 4 & 236 & 8 & $6 / 11$ & 219 & 12 \\
\hline 5 & 236 & 11 & $29 / 50$ & 220 & 15 \\
\hline 6 & 208 & 11 & $2 / 4$ & 192 & 17 \\
\hline 7 & 226 & -2 & $1 / 2$ & 209 & 2 \\
\hline Group Mean & 222 & 10 & $7 / 14$ & 206 & 15 \\
\hline
\end{tabular}

* Equivalent to an anticlockwise rotation of $22^{\circ}$ about Euler pole at $96.5^{\circ} \mathrm{E}, 73^{\circ} \mathrm{N}$ and a $38^{\circ}$ clockwise rotation about a Euler Pole at $27.7^{\circ} \mathrm{E}, 88.5^{\circ} \mathrm{N}$. Dp and $\mathrm{dm}$ are the radii of the 95 percent confidence oval in the colatitude direction and at right angles to it respectively.
America (Irving \& McGlynn 1976, Fig. 4, McElhinny 1973, Fig. 110).

(iii) Comparison with palaeomagnetic data from the kimberlite-lamprophyre province

Palaeomagnetic results from the West Greenland kimberlite/lamprophyre province include data from three dykes on the island of Sagdlerssuaq and one dyke at Itivdleq reported by Beckmann \& Mitchell (1976), and from fifty-two dykes studied by the present author. Characteristic mean directions of magnetisation after a.f. and thermal cleaning are plotted in Fig. 4 in the context of regional location across the Nagssugtoqidian Belt; magnetite, often of low coercivity, is the remanence carrier in most of these dykes although hematite is locally an important carrier near the southern margin of the belt.

Magnetic properties of the kimberlite/lamprophyre suite are discussed in detail elsewhere (Piper 1981); here the geological implications of the data and their relationship to pseudotachylite formation are noted. Firstly it is clear from Fig. 4 that an appreciable number of kimberlite/lamprophyre dykes have directions of magnetisation similar to the pseudotachylites and a comparable age is indicated. One dyke (site 44 in the Itivdleq area) also has a reversed magnetisation with respect to the remainder although the inclination $\left(-4^{\circ}\right)$ is somewhat less than pseudotachylite site 3 . However, it is also apparent that the kimberlite/lamprophyre magmatism was not such a limited event as the pseudotachylite formation: directions of magnetisation are non-Fisherian and distributed along a swathe between shallow westerly and near vertical areas of the stereonet (Fig. 4). Since secondary components are believed to have been effectively removed by the cleaning treatment, the simplest explanation of this is that the dykes record intrusion over a long period of time or a period of rapid a.p.w. movement. When the kimberlite/lamprophyre site mean directions are plotted area by area across the Nagssugtoqidian belt ((i) to (iv) in Fig. 4A) considerable differences are apparent: near the axis of the belt at Sagdlerssuaq the bulk of the dykes have westerly shallow negative to positive directions. In the Manitsorssuaq-Sarfanguaqland area further removed from the axis, the bulk of the directions are still westerly but with more positive inclinations. Also the pseudotachylites of sites 4 and 5 cut two kim- 


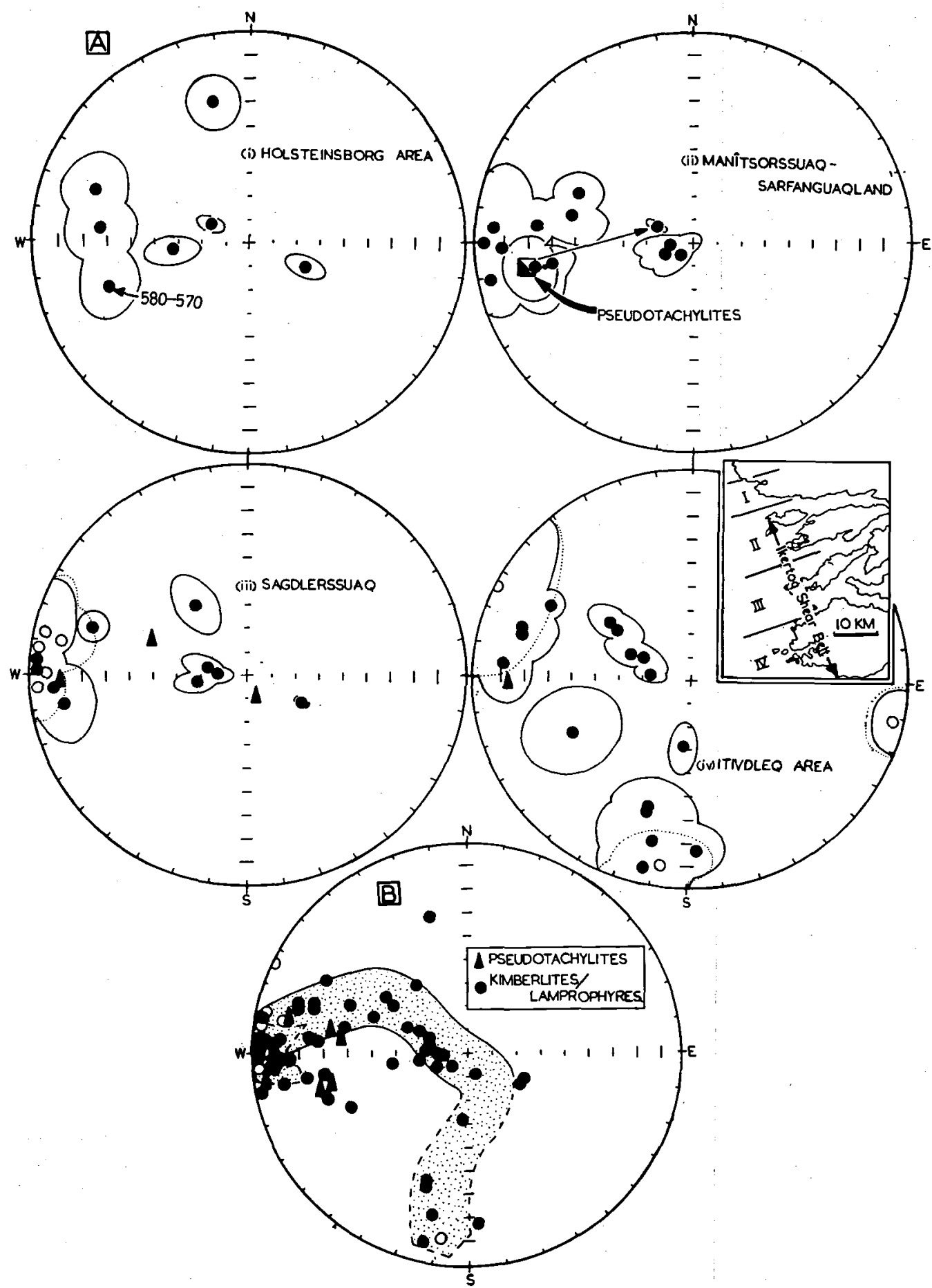

Fig. 4. A. Directions of magnetisation and 95 percent confidence circles from lamprophyre and kimberlite dykes plotted area by area (inset map) across the Nagssugtoqidian belt and compared with the pseudotachylite mean direction from the ManitsorssuaqSarfanguaqland area. The arrows in (ii) indicate the direction of palaeofield migration as shown by cross-cutting relationships in this area. B. The distribution of site mean directions from the kimberlite-lamprophyre province (circles) together with the means from four sites (triangles) given by Beckmann \& Mitchell (1976); the swathe indicates the generalised palaeofield migration inferred from these data (see text). 
berlite dykes (16 and 18) and define the direction of palaeofield migration (Fig. 4) from shallow to steep. They imply that the elongate distribution of site mean directions represents a migration of the palaeofield axis as indicated in Fig. 4B. Towards the northern (i) and southern (ii) margins of the belt the directions are more scattered, and tend to be of steeper inclination. The southern margin of the belt is also characterised by a group of southerly directions which are in accord with Silurian palaeofield directions from North America (Piper 1981). Thus emplacement of the kimberlite/lamprophyre suite was concentrated earliest near the axis of the Ikertôq shear belt; intrusion was later and more protracted near the margins, and immediately outside, of this belt. This is a general trend only because steep inclinations are found in dykes throughout the belt, and it is best summarised in Fig. 5 where the distance of the sampling site from the geometrical axis of the Ikertôq sheet belt (assumed to run through Qeqertalik, Fig. 5 inset) is plotted against the distance along the palaeofield migration path assumed in Fig.

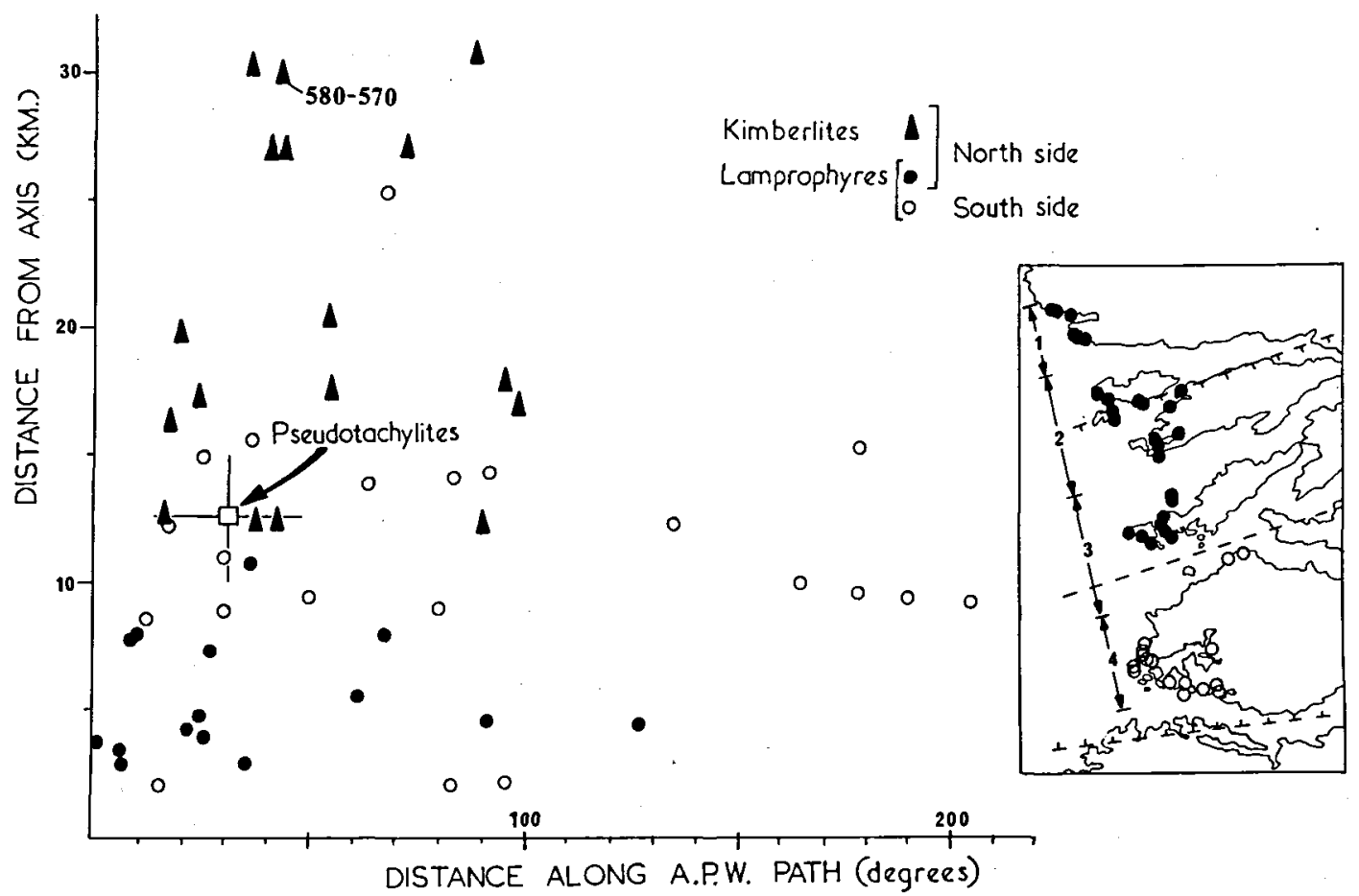

Fig. 5. The distance of site mean directions of magnetisation of the kimberlite and lamprophyre dykes plotted as a function of distance along the swathe shown in Fig. 4B (an approximate indication of relative age) and plotted against their distance from the axis of the Ikertô Shear Belt as shown by Bak et al. (1975). Where no petrographic subdivision is available (area not covered by Scott (1977)) sampled dykes have been arbitrarily included with the lamprophyres.

4B: whilst there is a tendency for the oldest dykes to occur near the axis, intrusion was protracted throughout the belt. The palaeofield migration path also predicts that the pseudotachylites of this study from near the northern margin of the belt postdate the oldest kimberlites and lamprophyres near the axis of the belt at Sagdlerssuaq but (as is locally observed) predate the dykes with a magnetic inclination averaging more than about $22^{\circ}$.

These observations on age variation across the kimberlite/lamprophyre province complement geochemical observations: Scott (1977) finds that kimberlite dykes intrude predominantly granulitic facies rocks near both margins of the Ikertôq shear belt, whereas lamprophyre dykes intrude amphibolite-facies rocks (although some occur within the granulite augen identified by Bak et al (1975) north of Itivdleq). Scott (1981) also reports a $\mathrm{Rb}-\mathrm{Sr}$ isochron by $\mathrm{C}$. B. Smith of $1227 \pm 12 \mathrm{Ma}$ for three of the potassic lamprophyre dykes. The palaeofield axis for Greenland at $c a .1220 \mathrm{Ma}$ is $\mathrm{D}=290^{\circ}, \mathrm{I}=-10^{\circ}$ (Piper $\&$ Stearn 1977) and would be consistent with the 


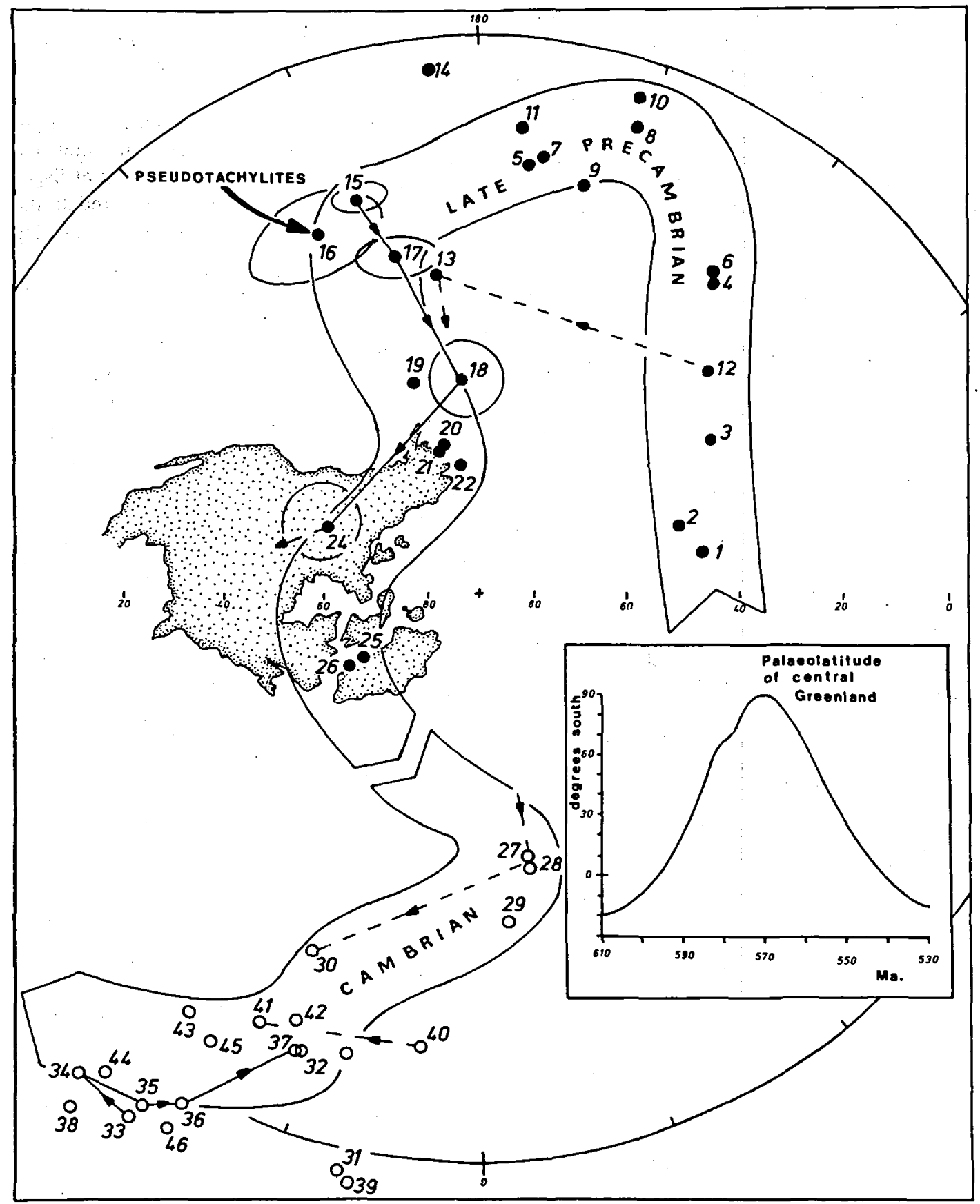

Fig. 6. The Hadrynian a.p.w. track connecting poles of known or probable late Precambrian age (closed circles) and Cambrian (open circles) age. This track is defined in part by the sequence of poles 15, 17, 18 and 24 (K2-K5) ca. 580-550 Ma from the kimberlite-lamprophyre suite in West Greenland; other poles are: 1-5, Colorado intrusives (704-485 Ma); 6,7, Iron MountainMaclure Mountain alkaline complex; 8, 9, Franklin rocks A and B; 10, Johnnie Formation; 11, Cloud Mountain basalt (605 Ma); 12, 13, Lamotte Formation, poles 1 and E; 14, Quebec lavas A (564 Ma); 19, Grand Canyon Group, pole 13; 20, Rapitan Group Y; 21, Orienta; 22, Little Dal 'C'; 25; Jacobsville Formation 'C'; 26, Chequemegon; 27, Lamotte Sandstones, 2a; 28, Bonneterre Dolostone; 29, Lodore Formation; 30, Lamotte Sandstones, 2b; 31, Waynesboro Formation (L-M Cambrian); 32, Wilberns Formation (U. Cámbrian); 33, Hickory Sandstone; 34, Cap Mountain Limestone; 35, Lion Mountain Limestone; 36, Welge Sandstone/Morgan Creek Limestone; 37, Point Peak Shale (poles 33-37, late Middle to early Upper Cambrian and in stratigraphic order); 38, Rome Formation (L-M Cambrian); 39, Bradore Sandstones (L. Cambrian); 40, 41, Quebec lavas ' $B$ ' and 'C'; 42, Tapeats Sandstone (L-M Cambrian); 43, Quebec ophiolite; 44, 45, 46, Wichita Granites (525 Ma). For summary of poles and references see Piper (1981). 
shallowest westerly directions of magnetisation found in lamprophyre dykes from the axial part of the shear belt (Fig. 5). It appears that the dykes yielding these directions reflect reactivation of the belt at two different times but they cannot be discriminated on palaeomagnetic grounds because the palaeofield axes at $c a .1220$ and $600 \mathrm{Ma}$ were nearly identical (eg. Irving \& McGlynn 1976).

(iv) A. p. w. path and Late-Precambrian-Cambrian motions of Greenland.

By grouping the kimberlite-lamprophyre site mean directions (Fig. 4B) into approximately $30^{\circ} \times 30^{\circ}$ sectors of the stereonet, a sequence of mean poles can be calculated to represent the palaeofield migration from westerly shallow to steep positive (Piper 1981) with the reservation that the shallowest (K1) direction includes $c$. $1230 \mathrm{Ma}$ material. These are plotted in sequence as poles 15, 17, 18 and 24 in Fig. 6 with 95 percent confidence ovals together with the pseudotachylite mean pole relative to North America after correction for the Phanerozoic drift of Greenland (Table 2, Bullard et al. 1965). They define part of a long track originally outlined and named the "Hadrynian Track" by Morris \& Roy (1977), connecting late Precambrian and Lower Cambrian palaeopoles. Unfortunately few of these data have assigned radiometric ages but the Greenlandic poles clearly fall between pole 11 dated at $605 \mathrm{Ma}$ and Lower Cambrian poles; the Lower Cambrian is assigned to the approximate interval $560-530 \mathrm{Ma}$ by Cowie \& Gibb (1978). The steep inclination magnetisations 19-23, 25 and 26 are derived from the multicomponent magnetisation record of certain sedimentary sequences and the precise age of these magnetisations is not established (Morris \& Roy 1977).

The palaeomagnetic data alone are insensitive to the longitudinal motions of the Laurentian Shield but the a.p.w. path of Fig. 6 can be translated into the equivalent palaeolatitudinal movement. This is illustrated in the inset diagram for central Greenland at latitude $67^{\circ} \mathrm{N}$ and shows that Greenland moved rapidly away from equatorial to polar latitudes in latest Precambrian times and back to low latitudes by Lower Cambrian times; it remained in low latitudes through the remainder of Palaeozoic times. A tillite which correlates with this short movement to high latitude occurs in southern Peary Land (Troelsen 1956, Clemmensen 1975). The underlying rocks here include some dolomite units, and they are associated with sandstones and overlain by Lower Cambrian and younger rocks which include limestones and then dolomites (Dawes 1976). The horizon would correlate with the migration of Greenland across the south pole (as illustrated in Fig. 6) in latest Precambrian early Lower Cambrian times and the rapid change in palaeoenvironments would accord with the rapid changes in palaeolatitude concentrated within the interval approximately 580$540 \mathrm{Ma}$.

(v) Regional significance of the pseudotachylitekimberlite-lamprophyre association

The recognition that pseudotachlylites are closely linked to the spisode of alkaline magmatism in Late Precambrian-Lower Cambrian times identifies the Ikertôq and Itivdleq shearbelts as zones of reactivation over a period of $c a .30 \mathrm{Ma}$ at about $580-560 \mathrm{Ma}$. The distribution of pseudotachylite mean directions of magnetisation is more restricted than the distribution shown by the lamprophyres and kimberlites (Fig. 4) implying that the events producing these veins were a limited phase of the overall activity. However, the present sample is also more limited, and more extensive sampling across the shear belts would be necessary to establish whether this is really the case. Also it is stressed that these results do not require that all of the pseudotachylites in West Greenland are of Cambrian age and linked to the kimberlite-lamprophyre episode. Some pseudotachylites in the Ikertôq belt appear to have formed between ductile movements while the metamorphic rocks were still at elevated temperatures (Bak et al. 1975). Also in the Nagssugtoqidian Belt in East Greenland, where isolated Cambrian kimberlites are also present (Mitchell 1978); Beckmann (1979) reports that one pseudotachylite has a remanence direction similar to the basement rocks (the amphibolite/granulite directions in Fig. 3), and was thus probably also formed during the earlier ductile phases of deformation.

Doig (1970) has demonstrated that a widespread $c a$. 570-560 Ma alkaline province including carbonatites, gabbros and syenites is associated with the St. Lawrence graben and he links it with certain Greenlandic localities and contem- 


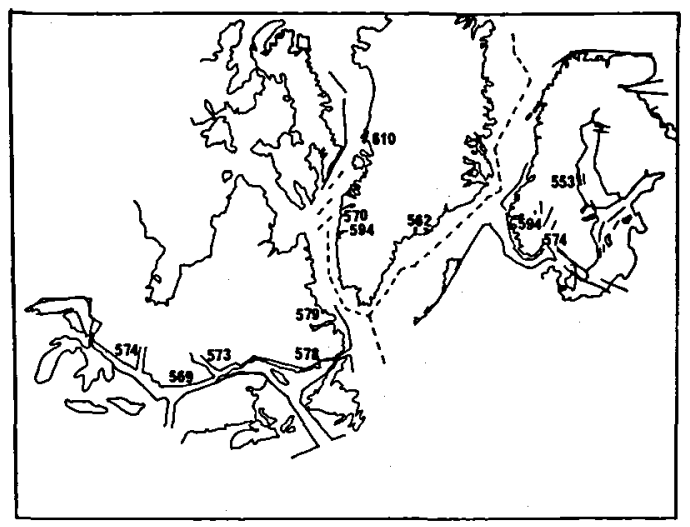

Fig. 7. The distribution of the ca. $560 \mathrm{Ma}$. alkaline province on the pre-drift reconstruction of Bullard et al. (1965, and valid for Late Precambrian times with minor modification (eg. Patchett and Bylund (1978)). Modified after Doig (1970) with graben faults of Late Precambrian-Lower Palaeozoic age. The age data are recalculated to revised decay constants (Dalrymple 1979).

poraneous events in the Fennoscandian Shield. Fig. 7 is an updated version of his Fig. 4, including the data from Greenland and revised age estimates of the age of the Fennoscandian activity (Kresten et al. 1977, Dalrymple 1979). The great majority of these occurrences can be linked to graben faulting controlled by older basement structures. This graben system also appears to have limited the encroachment of the Lower Cambrian seas, (Doig op. cit.), and Fig. 7 emphasises the widespread nature of the c. 560 $\mathrm{Ma}$ alkaline event which was appreciably more extensive than subsequent alkaline magmatic episodes (Doig 1970, MacIntyre 1971).

(vi) Late Precambrian glass

On the context of a Cambrian age, the survival of unaltered glass at site 2 is particularly noteworthy: with the exception of meteoritic material, nearly all glasses are Miocene or younger (Marshall 1961). In 1961 only one Cretaceous volcanic glass was known and one Ordovician perlite (Marshall op. cit.). In these veins the preservation of glass is probably exceptional because brittle deformation in the Ikertôq belt was almost always accompanied by retrogression of hornblende to chlorite (Grocott 1977). The implied presence of water at temperatures of $100-200{ }^{\circ} \mathrm{C}$ would in general have promoted crystallisation of any glass during episodes of reactivation in the shear belt.

Acknowledgements. This work is supported by Natural Environment Research Council Grant GR3/2398. I am grateful to
Dr R. L. Smith for help with the sampling, Mrs. Joan Dean for making a.f. demagnetisation measurements and $\mathrm{Dr} \mathrm{J}$. Watterson for providing logistical help. This work has also benefited from valuable discussions with Dr Watterson and I thank Dr J. Grocott for help with fieldwork and for bringing my attention to a number of points of interpretation.

\section{Dansk sammendrag}

Pseudotachylit årer fra den nordlige rand af Ikertôq shear området besidder en sardeles stabil remanent magnetisme $i$ magnetit. Prøver fra 7 årer viser en magnetiseringsakse med en deklination på $269^{\circ}$ og en inklination på $22^{\circ}$. En af årerne viser en modsat polaritet. De paleomagnetiske resultater viser at frakturerne, som er repræsenterede ved pseudotachyliterne, kan opfattes som én episode. I nogle af kimberlit/lamprophyr gangene i Ikertôq bæltet findes den samme magnetisering. Dette antyder samtidighed mellem pseudotachyliterne og den tidlige del af kimberlit/lamprophyr intruderingen (alder ca. 580 mill. år). Pseudotachyliterne omfatter de ældste kendte glasser.

Kimberliterne og lamprophyrerne har en ikke-Fischersk fordeling af den remanente magnetisme som antyder, at de er intruderet $i$ en periode med en hurtig og stor tilsyneladende polvandring $\mathbf{i}$ den yngste Prækambriske tid. Intrusionen af kimberliterne og lamprophyrerne fandt $i$ begyndelsen sted tæt ved aksen i Ikertôq bæltet (sandsynligvis lige før dannelsen af pseudotachyliterne) og i slutningen tæt ved kanterne af bæltet, hvor det synes at have fortsat ind $\mathrm{i}$ Paleozoisk tid.

De samlede paleomagnetiske data viser at Grønland bevægede sig hurtigt over sydpolen i yngste Prakambrium/ældste Kambrium hvilket passer vel med den stratigrafiske alder af de sydlige tilliter på Peary Land.

\section{References}

Bak, J., Sørensen, K., Grocott, J., Kortsgård, J. A., Nash, D. and Watterson, J. 1975: Tectonic implications of Precambrian shear belts in western Greenland. Nature Lond. 254: 566-569.

Beckmann, G. E. J. 1979: A review of Nagssugtoqidian palaeomagnetism. Rapp. Gronlands geol. Unders. 89: 115-124.

Beckmann, G. E. J. and Mitchell, J. G. 1976: Palaeomagnetic and geochronological work in central west Greenland. Earth Planet. Sci. Lett. 30: 269-280.

Bridgwater, D. 1971: Routine K-Ar age determinations on rocks from Greenland carried out for GGU in 1970. Rapp. Gronlands geol. Unders. 25: 52-60.

Bridgwater, D., Escher, A., Nash, D. C. and Watterson, J. 1973: Investigations on the Nagssugtoqidian boundary between Holsteinberg and Kangamiut, Central West Greenland, Rapp. Gronlands geol. Unders. 55: 22-25.

Bullard, E. C., Everett, J. E. and Smith, A. G. 1965: The fit of the continents around the Atlantic. Phil. Trans. R. Soc. Lond. $A$, 258: 41-51.

Clemmensen, L. B., 1975. Notes on the palaeogeographical setting of the Eocambrian tillite-bearing sequence of southern Peary Land, North Greenland. Rapp. Grønlands geol. Unders. 88; 15-22.

Cowie, J. W. and Cribb, S. J. 1978: The Cambrian System. In: G. V. Glaessner, M. F. and Hedberg, H. D. (eds.) The Geologic Time Scale. Amer. Assoc. Petrol. Geol. 335362. 
Dawes, P. R. 1976: Precambrian to Tertiary of northern Greenland. In: Escher, A. and Watt, W. S. (eds.) Geology of Greenland. Grønlands geol. Unders. Copenhagen pp 249-303.

Doell, R. R. and Cox, A. 1967: Palacomagnetic sampling with a portable drill. In: Collinson, D. W., Creer, K. M. and Runcorn, S. K. (eds.) Amsterdam Elsevier, 21-25. Methods in Palaeomagnetisne.

Doig, R. 1970: An alkaline rock province linking Europe and North America. Can. J. Earth Sci. 7: 22-28.

Dalrymple, G. B. 1979: Critical tables for conversion of K-Ar ages from old to new constants. Geology 7: 558-560.

Escher, A. and Watterson, J. 1973: Kimberlites and associated rocks in the Holsteinsberg - Sondre Stromfjord region, central West Greenland. Rapp. Gronlands geol. Unders. 55: $26-27$.

Fahrig, W. F. and Bridgwater, D. 1976: Late Archaean Early Proterozoic palaeomagnetic pole positions from West Greenland. In: Windley, B. F. (ed.) The Early History of the Earth. John Wiley, London, 427-439.

Grocott, J. 1977: The northern boundary of the Ikertog shear belt, West Greenland. Ph. D. thesis, University of Liverpool.

Irving, E. 1964: Palaeomagnetism and its application to Geological and Geophysical Problems. 399 pp. John Wiley, New York.

Irving, E. and McGlynn, J. C. 1976: Proterozoic magnetostratigraphy and the tectonic evolution of Laurentia. Phil. Trans. R. Soc. Lond. A 280: 433-468.

Kresten, P., Printzlau, I., Rex, D., Vartianen, H. and Walley, A. 1977: New ages of carbonatite and alkaline ultramafic rocks from Sweden and Finland. Geol. Foren. Stockh. Forh., 99: 62-65.

MacIntyre, R. M. 1971: Apparent peridocity of carbonatite emplacement in Canada. Nature Lond. Phys. Sci., 12: 7981.

MacIntyre, R. M., Pringle, I. R. and Andrews, J. R. 1979: Age of West Greenland kimberlites. Abstract, Kimberlite symposium II.

Marshall, R. R. 1961: Devitrification of natural glass. Geol. Soc. Amer. Bull. 72: 1493-1520.
McElhinny, M. W., 1973: Palaeomagnetism and plate tectonics. 373 pp. Cambridge University Press.

Mitchell, J. G. 1978: Potassium-Argon ages from Phanerozoic basic dykes in South East Greenland. Rapp. Gronlands geol. Unders. 90: 141-145.

Morgan, G. E. 1976: Palaeomagnetism of a slowly cooled plutonic terrain in western Greenland. Nature Lond. 259: 382-385.

Morris, W. A. and Roy, J. L. 1977: Discovery of the Hadrynian. Polar Track and further study of the Grenville Problem. Nature Lond. 266: 689-292.

Nagata, T. 1967: Identification of magnetic minerals in rocks using methods based on their magnetic properties. In: Collinson, D. W., Creer, K. M. and Runcorn, S. K. (eds.) Methods in Palaeomagnetism. Elsevier, Amsterdam, 501-513.

Patchett, P. J. and Bylund, G. 1978: Age of Grenville belt magnetisation: $\mathrm{Rb}-\mathrm{Sr}$ and palaeomagnetic evidence from Swedish dolerites. Earth Planet. Sci. Lett. 35: 92-104.

Piper, J. D. A. 1977: Magnetic stratigraphy and magneticpetrologic properties of Precambrian Gardar lavas, South Greenland. Earth Planet. Sci. Lett. 34: 247-263.

Piper, J. D. A. 1981: Palaeomagnetic study of the (Late Precambrian) kimberlite-lamprophyre suite, West Greenland; Definition of the Hadrynian Loop. Phys. Earth. Planet. Int. (in press.)

Piper, J. D. A. and Stearn, J. E. F. 1977: Palacomagnetism of the dyke swarms of the Gardar Igneous Province, South Greenland. Phys. Earth Planet. Int. 14: 345-358.

Pullaiah, G., Irving, E., Buchan, K. L. and Dunlop, D. J. 1975: Magnetisation changes caused by burial and uplift. Earth Planet. Sci. Lett. 28: 133-143.

Scott, B. H. 1977: Petrogenesis of kimberlites and associated potassic lamprophyres from central West Greenland. $\mathrm{Ph}$. D. Thesis, University of Edinburgh.

Scott, B. H. 1981: Kimberlite and lamproite dykes from Holsteinsborg, West Greenland. Meddr. Grønland, Geoscience 4: 3-24.

Troelsen, J. C. 1956: The Cambrian of North Greenland and Ellesmere Island. In: EI sistema Cambrico, su palaeogeographia y el problem de su base. 20 Congr, Geol. Int. Mexico Symp. 3 (1) 71-90. 